\title{
Levels of Shading and Reflective Material in Benches for Schizolobium amazonicum Seedlings
}

\author{
Roberto Kennedy Mortate ${ }^{1}$, Edilson Costa $^{1}$, Gustavo Haralampidou da Costa Vieira ${ }^{1}$, Heitor Franco de Sousa ${ }^{2}$, \\ Renato Silva Borges ${ }^{1}$, Willams Ferreira Souza Barbosa ${ }^{1} \&$ Geany Giovana Silva Costa ${ }^{1}$ \\ ${ }^{1}$ School of Agronomy, University Estadual de Mato Grosso do Sul, Cassilândia, Brazil \\ ${ }^{2}$ School of Agronomy, University Federal de Goiás, Jataí, Brazil \\ Correspondence: Roberto Kennedy Mortate, Postgraduate Sustainability in Agriculture, Agronomy, University \\ Estadual de Mato Grosso do Sul, Cassilândia, Brazil. Tel: 55-679-8136-5404. E-mail: \\ roberto.mortate@gmail.com
}

Received: February 1, 2019

Accepted: March 3, $2019 \quad$ Online Published: April 15, 2019

doi:10.5539/jas.v11n5p485

URL: https://doi.org/10.5539/jas.v11n5p485

\begin{abstract}
High quality forest seedlings are essential for the implementation of a commercial forest system, and it is therefore necessary to study their development in different environments, seeking to identify the most favorable environment for their production. In view of the above, the purpose of this essay was to evaluate the production of quamwood seedlings in different environments and workbenches with reflective material. The study was conducted at the State University of Mato Grosso do Sul-Cassilândia-MS from August to November 2017, in a completely randomized design within each environment and the environments compared by the joint analysis of the data. At the opportunity, produced quamwood seedlings under shade levels of $0 \%$ (full sun), 30\% under sombrite, $35 \%$ under thermo-reflective screen and the agricultural greenhouse with thermo-reflective screen under the film with $42 / 50 \%$ shading. In the interior of each environment the seedlings were placed on cultivation benches with reflective material (aluminum paper) and without reflective material. The environments were compared by the joint analysis, and the results of molt height and lap diameter were measured at 30,55 and 72 days after transplanting. The experiment was completed at 72 days after transplanting and the destructive analysis of the seedlings was performed, subjecting them to drying in a forced ventilation oven until reaching a constant dry mass. Based on the results obtained, the total dry mass, height and diameter ratio, root dry mass ratio and dry mass root system, absolute growth rate and Dickson quality index were calculated. The protected environments were favorable to the formation of paricá seedlings. The environment in full sun formed small, but more rustic seedlings. The use of reflective material had a positive effect only in the plastic coverage environment with $42 / 50 \%$ shading screen.
\end{abstract}

Keywords: Schizolobium amazonicum, forest seedlings, photosynthetically active radiation

\section{Introduction}

Paricá (Schizolobium amazonicum Huber ex Ducke) is a species native to the Amazon rainforest and is widely used for reforestation of degraded or deforested areas due to its rapid growth and heterogeneity in planting (Gondin et al., 2015). The same authors report that in view of their great productive and economic potential, many producers are awakening to their cultivation and this way it is necessary to know the development of the same, mainly in the production of seedlings with high quality, in less time, with low mortality in the field and with low production costs. Therefore, studies with plant environment are necessary to evaluate the best conditions for the initial growth of the species.

In order to produce quality seedlings, suitable conditions are required for adequate growth and adequate development of the seedlings, in order to reduce environmental interference with temperature, humidity, wind, rainfall, pests and, especially, light. As a primary source of energy, light is directly related to the photosynthetic efficiency (Taiz \& Zeiger, 2004) and the correct supply in quantity and quality provide, besides adequate conditions, better assimilation by the vegetable.

There is a wide range of responses from plants to light depending on the species in cultivation, making the quality and quantity of light, or even their absence, as limiting or stimulating factors for the growth and 
vegetative development of the aerial part and survival of the seedlings (Caron et al., 2010; Barbosa et al., 2013). Many studies report the environmental conditions against the availability of the photosynthetically active radiation for the development and plasticity of the plants (Almeida et al., 2005; Campos \& Uchida, 2002).

Studies with photosynthetically active radiation incident, reflected above, and below the canopy of Atlantic forest in Coruripe-AL have shown that factors such as the position of the sun, atmospheric conditions and vegetation structure affect the solar radiation regime within a forest (Andrade et al., 2014). Therefore, studies with different types of protected environments and reflective material in cultivation beds, aiming at the best availability of radiation to the plant, are essential in the plant environment of Schizolobium amazonicum.

Studies with the emergence of seedlings and seedling formation of Schizolobium amazonicum on ten different substrates and two shadings ( 0 and 50\%) were observed that substrates land, coconut shell and coconut shell + sand in environment with 50\% shading, and soil, soil + sand and coconut shell + sand in full sun promoted the best seedlings (Gondin et al., 2015).

Studies with reflective material in culture benches were performed by Santos et al. (2017) who verified using a mirror in the seedlings of passion fruit seedlings presented a higher growth rate, shoot dry matter than the use of "false paetê" tissue. For jambolão seedlings, there was influence of the reflective material in the cultivation bench (aluminum foil) that provided the best seedlings in a shaded environment with $30 \%$.

Considering the large degraded areas existing in the country, wich reach 140 million hectares (IBGE, 2012) and the fact that paricá presents great potential for commercial exploitation and at the same time recovering such degraded areas, the objective of this work was to evaluate the production of paricá seedlings grown under different shaded environments and reflective material, determining wich produces vigorous seedlings.

\section{Method}

The experiment to evaluate the formation of paricá seedlings (Schizolobium amazonicum) was conducted in Vegetation House at the State University of Mato Grosso do Sul (UEMS), University Unit of Cassilândia (UUC), located in the municipality of Cassilândia (latitude $19^{\circ} 07^{\prime} 21^{\prime \prime} \mathrm{S}$, longitude of $51^{\circ} 43^{\prime} 15^{\prime \prime} \mathrm{W}$ and $516 \mathrm{~m}$ altitude during the period from August to November 2017. According to Köppen's climatic classification, the region presents Tropical Rainy Weather (Aw), characterized by being warm and humid, with two seasons defined, rainy in summer and dry in winter (Koppen \& Geiger, 1961).

Shade levels were studied, as well as cultivars with reflective material in the formation of paricá seedlings (Schizolobium amazonicum). The environments used were: 1) Environment in full sun, with $0 \%$ shading, (A1); 2) agricultural structure, of galvanized steel structure, having $8.00 \mathrm{~m}$ wide by $18.00 \mathrm{~m}$ long and $3.50 \mathrm{~m}$ high,

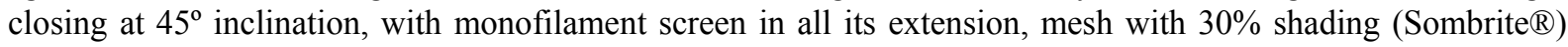
(A2); 3) agricultural roof of $18.0 \mathrm{~m}$ long by $8.0 \mathrm{~m}$ wide and $3.50 \mathrm{~m}$ high, closed at 45 degrees, with ALUMINET ${ }^{\circledR}$ aluminized heat-reflecting screen $35 \%$ shading (A3) and; 4) $18.0 \mathrm{~m}$ long $8.0 \mathrm{~m}$ wide, $4.0 \mathrm{~m}$ high greenhouse covered with 150 micron low density polyethylene (LDPE) film, light diffuser, antegotejo, sealed zenith aperture with white screen of $30 \%$, with side screen and front of monofilamento of $30 \%$ of shadowing. LuxiNet 42/50 aluminised thermo-reflective screen, mobile, under LDPE film (A4).

The benches on which the seedlings were distributed consisted of: 1) bench without reflective material; 2) bench with reflective material, covered with aluminum foil to enlarge the photosynthetically active radiation to the plants. The types of benches were spaced $2.0 \mathrm{~m}$ apart so that there was no interference from the reflection of aluminum foil. The seedlings on the benches were spaced between $15.5 \mathrm{~cm}$ lines.

The sowing was carried out on 08/11/2017 in a sandbox until stabilizing the emergence, the seedlings were selected and transplanted to polyethylene plastic bags (dimensions of $15.0 \times 25.0 \mathrm{~cm}$ and volume of $1.8 \mathrm{~L})(50 \%)$ + bovine manure $(30 \%)+$ vermiculite thin $(20 \%)$ and they were kept in a protected environment for acclimatization, and distributed in the different growing environments after one week (08/30/2017). The substrate used was subjected to analysis and the result of this analysis can be seen in Table 1.

Plant height (AP) data were measured at 30, 55 and 72 days after transplanting (DAT), using a graduated ruler measuring the distance from the plant collar to the apex of the stem meristem and neck diameter (DC) measured using a digital caliper (mm).

At 72 DAT, the dry mass of the aerial part (MSPA) and mass of the dry matter of the root system (MSSR) were obtained. It was dried in an oven with forced air circulation, at a temperature of $65^{\circ} \mathrm{C}$ until reaching a constant mass, and then the mass of the dry matter was measured in an analytical balance. From these data, the total dry mass (MST) was calculated using the sum of the MSPA and MSSR (MST = MSPA + MSSR), the ratio between 
height and diameter of the neck (RAD), shoot dry mass ratio and dry mass system (RMS), absolute growth rate (TCA) and Dickson quality index (IQD) (Dickson et al., 1960).

Table 1. Chemical analysis of the substrate used to fill the polyethylene plastic bags used for the production of paricá seedlings in different environments and countertops with reflective material. Cassilândia-MS, 2017

\begin{tabular}{|c|c|c|c|c|c|c|c|c|c|c|c|}
\hline $\mathrm{pH}$ & $P$ & K & $\mathrm{Al}$ & $\mathrm{H}+\mathrm{Al}$ & $\mathrm{Ca}$ & $\mathrm{Mg}$ & $\mathrm{Sb}$ & $\mathrm{T}$ & M.O. & $\mathrm{m}$ & $\mathrm{V}$ \\
\hline $\mathrm{CaCl}_{2}$ & \multicolumn{2}{|c|}{---- $\mathrm{mg} \mathrm{dm}^{-3}$---- } & \multicolumn{4}{|c|}{ - $\mathrm{cmol}_{\mathrm{c}} \mathrm{dm}^{-3}$} & - & ---- & \multirow{2}{*}{$\begin{array}{l}\mathrm{g} / \mathrm{kg} \\
63\end{array}$} & \multicolumn{2}{|c|}{----- \% ----- } \\
\hline 4.7 & 32.2 & 163 & 0.19 & 2.2 & 1.1 & 2.9 & 4.42 & 6.6 & & 4.1 & 66.8 \\
\hline $\mathrm{Cu}$ & $\mathrm{Fe}$ & $\mathrm{Mn}$ & \multicolumn{2}{|c|}{$\mathrm{Zn}$} & B & Sand & & Silt & & \multicolumn{2}{|l|}{ Clay } \\
\hline \multicolumn{6}{|c|}{----- Micronutrients $\left(\mathrm{mg} \mathrm{dm}^{-3}\right)$------ } & \multicolumn{6}{|c|}{----- Texture $\left(\mathrm{g} \mathrm{dm}^{-3}\right)$} \\
\hline 0.8 & 152 & 27.4 & & & 0.28 & 905 & & 25 & & 70 & \\
\hline
\end{tabular}

The photosynthetically active radiation $\left(\mu \mathrm{mol} \mathrm{m} \mathrm{m}^{-2}\right.$ ) was monitored by the Apogee brand in the cultivation environments, as well as in the cultivation grounds, and the radiation was measured on cloudy days (without cloud cover), always at the same time, at 9:30 AM. Radiation data were collected from August 30, 2017 to November 10, 2017 (Figures 1 and 2).

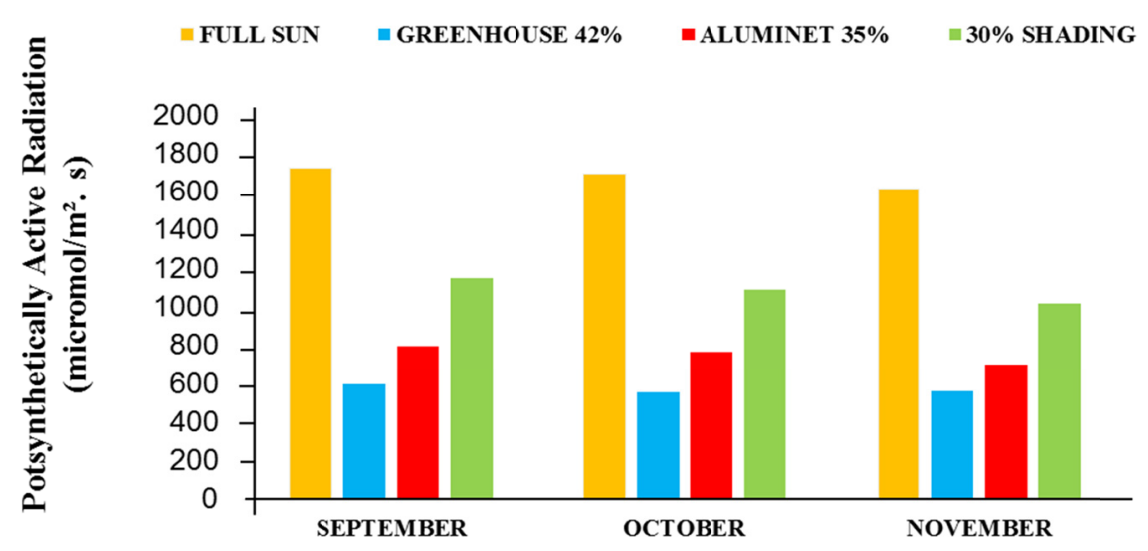

Figure 1 . Photosynthetically active radiation received within each environment
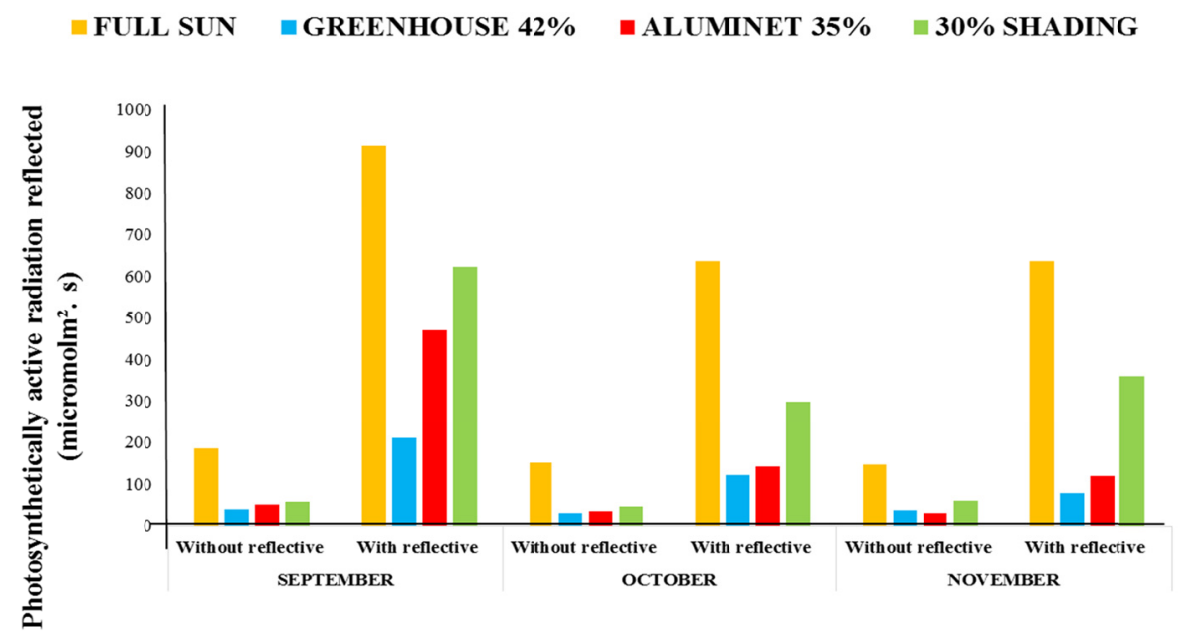

Figure 2. Photosynthetically active radiation reflected by the benches inside each environment

The data were submitted to analysis of variance ( $F$ test) and the means were compared by the Tukey test for the culture environments and the student $t$ test for the $5 \%$ probability of cultivation. Because there were no replications of shading levels, each was considered an experiment. We performed a joint evaluation of the 
environments, through the analysis of a group of experiments (Banzato \& Kronka, 2006) for those who presented a mean square root ratio of less than 7.0 composing a $4 \times 2$ factorial scheme (4 environments $\times 2$ benches ).

Within the environment, the experiment was conducted in a completely randomized experimental design, with 5 replicates of 4 seedlings each. To compare the levels of shading, the analysis of groups of experiments was used to evaluate the relationship between the largest and the smallest mean square of the residue.

\section{Results and Discussion}

In the studied variables, the plant height (AP2), the diameter of the colon (DC2; DC3), shoot dry mass (MSPA), total dry mass (MST), dry mass ratio by root dry mass (RMS), absolute growth rate (TCA) and Dickson quality index (IQD) showed interaction between environments and cultivars $(A \times B)$. The height of plants $(A P 1)$, the diameter of the neck (DC1) and the relationship between height and diameter of the neck (RAD1, RAD2 and RAD3) showed no interaction between the factors studied (Table 2).

Table 2. Analysis of variance for plant height (AP1, AP2, AP3), neck diameter (DC1, DC2, DC3), shoot dry mass (MSPA), dry mass of the root system (MSSR), total dry mass (RDS), dry matter ratio (RMS), Dickson quality index (IQD), and absolute growth rate (TCA) of paricá seedlings in different species levels of shading, and reflective material on benches. Cassilândia-MS, 2017

\begin{tabular}{|c|c|c|c|c|c|}
\hline Source of Variation & AP1 & AP2 & AP3 & DC1 & DC2 \\
\hline Environment (A) & $* *$ & $*$ & $* *$ & $* *$ & $* *$ \\
\hline Benches (B) & $* *$ & ns & $*$ & $* *$ & $*$ \\
\hline $\mathrm{A} \times \mathrm{B}$ & ns & $*$ & ns & ns & $* *$ \\
\hline $\mathrm{CV}(\%)$ & 11.75 & 12.98 & 9.81 & 5.77 & 6.83 \\
\hline Source of Variation & DC3 & MSPA & MSSR & MST & RAD1 \\
\hline Environment (A) & $* *$ & $* *$ & $* *$ & $* *$ & $* *$ \\
\hline Benches (B) & $*$ & ns & ns & ns & ns \\
\hline $\mathrm{A} \times \mathrm{B}$ & $* *$ & $* *$ & ns & $*$ & ns \\
\hline CV (\%) & 6.44 & 19.95 & 22.50 & 18.68 & 9.66 \\
\hline Source of Variation & RAD2 & RAD3 & RMS & IQD & TCA \\
\hline Environment (A) & $* *$ & $* *$ & ns & $* *$ & $* *$ \\
\hline Benches (B) & ns & ns & ns & ns & ns \\
\hline $\mathrm{A} \times \mathrm{B}$ & ns & ns & $*$ & * & $* *$ \\
\hline $\mathrm{CV}(\%)$ & 10.38 & 8.30 & 17.34 & 19.97 & 28.97 \\
\hline
\end{tabular}

Note. $*$ significant at $5 \%$ probability; $* *$ significant at $1 \%$ probability, ns $=$ not significant; $\mathrm{CV}(\%)=$ coefficient of variation.

In Table 3, the seedlings produced in the environment with plastic cover and $42 / 50 \%$ shading screen obtained the highest heights and diameter of the cervix in the first 30 days after transplanting. In this environment, the smallest amounts of radiation were measured (Figures 1 and 2), however, this did not interfere in the growth, as the diameter of the cervix accompanied the growth in height. In the sunshine environment (Table 3), where the luminous intensity on the seedlings was higher, the smaller heights and smaller diameter of the colon were verified.

At 30 DAT (Table 3), the bed with reflective material provided larger seedlings $(16.09 \mathrm{~cm})$ and neck diameter $(3.76 \mathrm{~mm})$ of paricá, due to the greater distribution of light intensity reflected between the lines of the seedlings (Figure 2).

Similar results were observed by Rosa et al. (2009), where the authors reported that the shading effect was positive in paricá seedlings, where they showed a linear increase in height in the juvenile phase, and the nursery seedlings demanded shading intermediate of $30 \%$, being that in this luminous intensity the seedlings present a greater rusticity and a higher standard of quality.

Cunha et al. (Erythrina velutina Wild) observed that the rapid growth in height was in a shaded environment, fact that occurs in most forest species, and that the rapid growth when shaded depends on the behavior of each species in function of their adaptability to these environments of low luminous intensity. 
At 30 days after transplanting, the seedlings produced on the screen $30 \%$ shading and $35 \%$ shading aluminized canvas presented higher heights on the benches without reflective material, and the highest growth in height in benches with reflective material was in the environments $35 \%$ shading aluminized and plastic cover with $42 / 50 \%$ shading screen. For the benches with and without reflective material, the smallest seedlings were obtained in the environment with plastic cover and $42 / 50 \%$ shading and in the other environments there was no difference between the materials.

When observing the height of seedlings (AP2) produced in the environment with plastic cover and $42 / 50 \%$ shading screen in benches without reflective material (Table 4), it was observed that they obtained higher heights when compared to the seedlings arranged in the stands with reflective material, which presented the smallest changes, and the other materials did not differ in the culture environments. It is possible to observe a possible shedding of the seedlings arranged in the benches without reflective material, considering that they are in the shaded environment with radiation restriction (Figures 1 and 2).

Table 3. Plant heights (cm) at 30 (AP1) and 72 (AP3) days after transplanting (DAT) and neck diameter (DC1 in $\mathrm{mm})$ at 30 DAT of paricá seedlings. Cassilândia-MS, 2017

\begin{tabular}{llll}
\hline Environment & AP1 & AP3 & DC1 \\
\hline Full sun & $9.92 \mathrm{C}$ & $14.20 \mathrm{~B}$ & $2.99 \mathrm{C}$ \\
Laying 30\% shading & $15.26 \mathrm{~B}$ & $28.17 \mathrm{~A}$ & $3.77 \mathrm{~B}$ \\
$35 \%$ Shading Aluminized Screen & $16.83 \mathrm{~B}$ & $31.85 \mathrm{~A}$ & $3.74 \mathrm{~B}$ \\
Screen with plastic cover 42/50\% shading & $19.17 \mathrm{~A}$ & $31.13 \mathrm{~A}$ & $4.07 \mathrm{~A}$ \\
\hline Benches & & \\
\hline Without reflective material & $14.50 \mathrm{~B}$ & $26.70 \mathrm{~A}$ & $3.53 \mathrm{~B}$ \\
With reflective material & $16.09 \mathrm{~A}$ & $25.97 \mathrm{~A}$ & $3.76 \mathrm{~A}$ \\
CV $(\%)$ & 11.75 & 12.41 & 5.77 \\
\hline
\end{tabular}

Note. Equivalent uppercase letters in the column, for each variable, do not differ by Tukey's test for the cultivation environments and $\mathrm{F}$ test for the cultivation grounds, AP1; DC1 $=1 \%$ probability; AP $3=$ environment at $1 \%$ probability; to $5 \%$ probability.

For the cultivation environments within each material (Table 4), the largest seedlings in the stand without reflective material were verified in the plastic covering environment and $42 / 50 \%$ shading and $35 \%$ shading aluminized canvas. For the worktops with reflective material, the plastic cover and $42 / 50 \%$ shading, 35\% shading, and $30 \%$ shading did not differ from each other obtaining the largest changes, differing only from the environment in full sun with smaller seedlings.

Scalon et al. (2005) studied the initial growth of Bombacopsis glabra (Pasq.) A. Robyns seedlings under shading condition, affirming that the increase in height of the forest species is higher when grown in environments with 30 and $50 \%$ shading. In a study with growth of Jacaranda puberula Cham. in nursery submitted to different levels of luminosity $(0,30,50$ and $70 \%)$, Almeida et al. (2005) state that at 60 days there was no difference in the growth of the seedlings in the growing environments and from the 90 days the highest heights were verified in an environment from $30 \%$ shading, similar to the results of the work, that from $30 \%$ shading the seedlings showed an increase in height.

According to Davide et al. (2005), the species belonging to the ecological group of climax species are tolerant to shade, being the species mentioned in the work belonging to the group of pioneers, it was expected a greater growth in the environment in full sun. However, these are recommended for planting in recovery programs of degraded areas and riparian forests (Almeida et al., 2003). 
Table 4. Plant height (AP2 cm) at 55 days after transplanting (DAT) of paricá seedlings. Cassilândia-MS, 2017

\begin{tabular}{lll}
\hline Plant height (AP2) & & \\
\hline Environment & Benches & \\
\hline Shading & Without reflective material & With reflective material \\
\hline Full sun & $10.57 \mathrm{aC}$ & $11.41 \mathrm{aB}$ \\
Laying 30\% shading & $19.02 \mathrm{aB}$ & $22.17 \mathrm{aA}$ \\
$35 \%$ Shading Aluminized Screen & $23.33 \mathrm{AB}$ & $24.41 \mathrm{aA}$ \\
Screen with plastic cover 42/50\% shading & $27.76 \mathrm{aA}$ & $23.75 \mathrm{bA}$ \\
\hline CV $(\%)$ & 12.98 & \\
\hline
\end{tabular}

Note. Lower case letters in the row and upper case in the column for each variable do not differ from each other by the Tukey test for the $1 \%$ probability and $t$ test for the cultivars at $5 \%$ probability.

According to Table 5, paricá seedlings presenting the smallest diameter of the colon at 55 days after transplanting were seedlings grown in full sun, regardless of the type of bench, with or without reflective material. On the other hand, the seedlings with the largest diameters at 55 days after transplanting were those that were in a plastic cover type environment with a $42 / 50 \%$ shading screen, regardless of the presence or absence of reflective material in the stands.

Table 5. Lapse diameter (DC2, DC3 mm) of paricá seedlings at 55 and 72 days after transplanting (DAT). Cassilândia-MS, 2017

\begin{tabular}{lll}
\hline Lapse diameter (DC2) & & \\
\hline Environment & Benches & \\
\hline Shading & Without Reflective material & With Reflective material \\
\hline Full sun & $4.00 \mathrm{aC}$ & $4.28 \mathrm{aB}$ \\
Laying 30\% shading & $5.39 \mathrm{bB}$ & $6.18 \mathrm{aA}$ \\
$35 \%$ Shading Aluminized Screen & $5.46 \mathrm{bB}$ & $5.96 \mathrm{aA}$ \\
Screen with plastic cover 42/50\% shading & $6.64 \mathrm{aA}$ & $6.23 \mathrm{aA}$ \\
\hline CV (\%) & 6.83 & \\
\hline Lapse diameter (DC3) & & $4.91 \mathrm{aC}$ \\
\hline Full sun & $5.25 \mathrm{aC}$ & $6.93 \mathrm{bB}$ \\
Laying 30\% shading & $8.25 \mathrm{aA}$ & $7.42 \mathrm{aB}$ \\
$35 \%$ Shading Aluminized Screen & $7.52 \mathrm{aAB}$ & $9.16 \mathrm{aA}$ \\
Screen with plastic cover 42/50\% shading & $7.30 \mathrm{bB}$ & \\
\hline CV $(\%)$ & 6.44 & \\
\hline
\end{tabular}

Note. Lower case letters in the row and upper case in the column, for each variable, do not differ by Tukey test for the cultivation environments and student $t$ test for the cultivation grounds, $\mathrm{DC} 2=5 \%$ probability; $\mathrm{DC} 3=1 \%$ probability.

However, the paricá seedlings developed in aluminized lattice with 35\% shading and 30\% shading cover showed the presence of reflective material in the stands showed a better increase in the diameter of paricá seedlings at 55 days after transplant when compared to the absence of reflective material on the benches. Thus, the increase in a larger diameter of the stem in the paricá seedlings is provided by the increase of the shading and the presence of reflective material in the stands.

The presence and/or absence of reflective material in the stands influenced directly the growth of the plant stem, regardless of the type of environment and the percentage of shading studied in the work. This is due to the fact that light is directly related to photosynthetic efficiency and quantity and quality supply directly influence the development of the vegetable (Taiz \& Zeiger, 2004).

The largest neck diameter at 55 days after transplanting, with absence of reflective material in the stands was the plastic cover type environment with $42 / 50 \%$ shading $(6.64 \mathrm{~mm})$ screen. 
However, the presence of reflective material did not favor plants grown in full sunlight, whereas for other environments, it provided good growth of the neck diameter at 55 days after transplanting. The paricá seedlings produced in full sun showed the smallest diameter of the colon at 72 days after the transplanting of the seedlings, regardless of the use of reflective material in the stands.

The diameter of the lap of the seedlings produced in the screened environment with $30 \%$ shading was favored by the absence of the reflective material on the benches, whereas for the environment with aluminized screen with $35 \%$ shading, the increase in the diameter growth of the seedlings of paricá, occurred regardless of the use or not of reflective material in the stands.

The use of reflective material on the benches inside the environment with plastic cover and $42 / 50 \%$ shading screen provided better development of the lap diameter of paricá seedlings in relation to the absence of reflective material.

Paricá seedlings allocated in environments with a 30\% shading and aluminized lattice with $35 \%$ shading, presented larger stem diameter at 72 days after transplanting in benches without reflective material and the seedlings allocated in benches with material also presented larger diameters at 72 DAT. Rosa et al. (2009), evaluating the diameter of the seedlings of paricá, reported that the best shading was intermediate of $30 \%$, which provided high quality seedlings in these conditions of production, corroborating with the results obtained in the present study.

On the other hand, Rosa et al. (2009) and Rosa (2006), observed that shading above 30\% impairs the diameter of the lap of the paricá seedlings, where it was verified that $70 \%$ of shading had a smaller diameter of the neck, however when using a shading of $42 / 50 \%$, the diameter of the neck was not impaired in the present study.

According to Azevedo et al. (2010), the diameter of seedlings of Marupá is favored with the level of $50 \%$ of shading. Lima et al. (2008), studying Caesalpinia ferrea seedlings, reported that the largest diameter of the colon was obtained in seedlings grown in full sunlight. According to Rosa et al. (2009), the parameter diameter of the colon, unlike the height parameter, is an important morphological parameter to evaluate the rusticity of paricá seedlings.

It should be noted that the height-to-diameter ratio (RAD), presents an equilibrium in the growth of the seedling and can demonstrate the occurrence of seedling growth (Costa et al., 2012). Campos and Uchida (2002), affirm that RAD is the parameter that indicates the quality of the seedling to be taken to the field, where the equilibrium in the development of seedling is expected completely.

RAD may be an indicative characteristic of seedling shedding in the nursery stage to detect possible seedlings that would fall from the plant to the field after planting, being able to demonstrate the balance of growth and determine field survival, since the lower its value, the better the moult survival ability after planting (Costa, 2015).

According to Table 6, when using reflective material or not under the countertops, there is no difference in the height/diameter ratio of paricá seedlings evaluated at 30,55 and 77 days after transplanting. The shading of $42 / 50 \%$ of shading in the screen-type environment with plastic cover provided higher RAD of the paricá seedlings lap at 30 days after transplanting, which was clearly superior to the others. However, it did not differ statistically from RAD in a 35\% shaded environment in aluminized cloth.

At 55 days after transplanting the RAD (Table 6) of paricá seedlings cultivated in an aluminized canvas with $35 \%$ shading showed superiority in relation to the others, however it did not differ statistically from the environment with screen with plastic coverage of $42 / 50 \%$ shading. 
Table 6. Height/diameter ratio (RAD1, RAD2, RAD3 cm/mm) at 30, 55 and 72 days after transplanting (DAT) of paricá seedlings. Cassilândia-MS, 2017

\begin{tabular}{llll}
\hline Environment & RAD1 & RAD2 & RAD3 \\
\hline Full sun & $3.30 \mathrm{C}$ & $2.63 \mathrm{C}$ & $2.79 \mathrm{C}$ \\
Laying 30\% shading & $4.03 \mathrm{~B}$ & $3.55 \mathrm{~B}$ & $3.71 \mathrm{~B}$ \\
$35 \%$ Shading Aluminized Screen & $4.47 \mathrm{AB}$ & $4.17 \mathrm{~A}$ & $4.26 \mathrm{~A}$ \\
Screen with plastic cover 42/50\% shading & $4.71 \mathrm{~A}$ & $3.99 \mathrm{AB}$ & $3.64 \mathrm{~B}$ \\
\hline Benches & & & $3.61 \mathrm{~A}$ \\
\hline Without reflective material & $4.04 \mathrm{~A}$ & $3.63 \mathrm{~A}$ & $3.58 \mathrm{~A}$ \\
With reflective material & $4.22 \mathrm{~A}$ & $3.54 \mathrm{~A}$ & 8.30 \\
\hline CV $(\%)$ & 9.66 & 10.38 & \\
\hline
\end{tabular}

Note. Equivalent letters in the column, for each variable, do not differ by Tukey's test for cultivation environments and student's $t$ test for cultivation grounds, environment $=1 \%$ probability, bench $=$ not significant.

At 72 days after transplanting the paricá seedlings, the highest RAD was verified in an aluminized screen environment with $35 \%$ shading (Table 6). In view of the above, the parica seedlings that presented the most suitable RAD to field transplanting were those allocated in a shaded environment at $35 \%$ and $42 / 50 \%$. Campos and Uchida (2002), studying Jacaranda capaia, verified that the use of $50 \%$ and $70 \%$ of shading provided higher values of RAD.

Taking into account the observations and conclusions reported by Costa (2015), where the seedlings with the lowest RAD value would have a greater capacity for field survival, it is observed that paricá seedlings grown in full sun the lower RAD, when compared to other cultivation environments, indicating rusticity, a fact that would require acclimatization when transplanted to the field.

It can be observed in Table 7 that the dry mass of the aerial part at 72 DAT, presented higher values when coming from seedlings grown in environments with $30 \%$ screened shading and 35\% aluminized screen, and it was not necessary to use benches with light reflecting material. These weights of the shoot masses were favored by the larger diameters of the seedlings collected from these same environments. Thus, the highest total dry mass (DMW) results were also observed in seedlings grown in shaded environments between 30 and 50\% shading.

When the weight of the dry mass of the root system (MSSR) is observed in Table 8, it is observed that although this parameter is not interactive between environments and stands with reflective material, the highest values were obtained from seedlings grown in shaded environments around 30 to $50 \%$ shading.

The radiation reflected by the reflecting material did not increase the ratio between the MSSR/MST of the seedlings produced in the different environments, which in turn did not influence the results either.

According to Table 9, when the values obtained by paricá seedlings for the MSPA/MSSR ratio were observed, the lowest ratio was observed in the environment with a plastic cover and $42 / 50 \%$ shading, and there were no differences for the same reason when observing the seedlings that received reflected radiation or not.

The growth rate of the paricá seedlings were influenced by the environment, as can be seen in Table 9. The environments with shading around $30-35 \%$ and without reflective material, provided a higher growth rate for paricá seedlings.

The Dickson quality index for paricá seedlings was reported by Rosa et al. (2009), where they could observe that paricá seedlings produced under $30 \%$ of shade had IQD of 0.52 , full sun $0.47,50 \%$ of shading 0.38 and $70 \%$ of shading 0.27 at 60 days after sowing. 
Table 7. Dry shoot mass (MSPA) and total dry matter (MST) at 72 days after transplanting (DAT) of paricá seedlings. Cassilândia-MS, 2017

\begin{tabular}{|c|c|c|}
\hline \multicolumn{3}{|l|}{ Dry shoot mass (MSPA) } \\
\hline Environment & Benches & \\
\hline Shading & Without Reflective material & With reflective material \\
\hline Full sun & $2.76 \mathrm{aC}$ & $2.30 \mathrm{aC}$ \\
\hline Laying $30 \%$ shading & $9.44 \mathrm{aA}$ & $6.47 \mathrm{bB}$ \\
\hline $35 \%$ Shading Aluminized Screen & $8.50 \mathrm{aAB}$ & $8.46 \mathrm{aAB}$ \\
\hline Screen with plastic cover $42 / 50 \%$ shading & $7.02 \mathrm{bB}$ & $10.38 \mathrm{aA}$ \\
\hline $\mathrm{CV}(\%)$ & 19.95 & \\
\hline \multicolumn{3}{|l|}{ total dry matter (MST) } \\
\hline Full sun & $3.80 \mathrm{aB}$ & $3.39 \mathrm{aC}$ \\
\hline Laying $30 \%$ shading & $11.87 \mathrm{aA}$ & $9.45 \mathrm{bB}$ \\
\hline $35 \%$ Shading Aluminized Screen & $12.93 \mathrm{aA}$ & $11.43 \mathrm{aAB}$ \\
\hline Screen with plastic cover $42 / 50 \%$ shading & $10.15 \mathrm{bA}$ & $13.93 \mathrm{aA}$ \\
\hline $\mathrm{CV}(\%)$ & 18.68 & \\
\hline
\end{tabular}

Note. Minuscule letters in the row and upper case in the column, for each variable, do not differ by Tukey test for the cultivation environments and student $\mathrm{t}$ test for the cultivation grounds, MSPA $=1 \%$ of probability; MST $=5 \%$ probability.

Table 8. Dry mass of the root system (MSSR) at 72 days after transplanting (DAT) of paricá seedlings. Cassilândia-MS, 2017

\begin{tabular}{ll}
\hline Environment & MSSR \\
\hline Full sun & $1.06 \mathrm{~B}$ \\
Laying 30\% shading & $3.17 \mathrm{~A}$ \\
35\% Shading Aluminized Screen & $3.22 \mathrm{~A}$ \\
Screen with plastic cover $42 / 50 \%$ shading & $3.34 \mathrm{~A}$ \\
\hline Benches & $2.76 \mathrm{~A}$ \\
\hline Without reflective material & $2.64 \mathrm{~A}$ \\
With reflective material & 22.50 \\
\hline CV $(\%)$ & \\
\hline
\end{tabular}

Note. Equivalent upper case letters in the column, for each variable, do not differ by Tukey's test for the cultivation environments and student's $t$ test for the cultivation grounds, environment $=1 \%$ of probability; bench $=$ not significant.

The data obtained in the present experiment for the IQD values (Table 9), also present differences as to the shading or not on the seedlings. It was observed that there was no difference between the shaded environments and that the use of reflective material was efficient only in the plastic greenhouse with shading $42 / 50 \%$. 
Table 9. Dry mass ratio (RMS = MSPA/MSSR), absolute growth rate (TCA-cm) and Dickson quality index (IQD) at 72 days after transplanting (DAT) of paricá seedlings. Cassilândia-MS, 2017

\begin{tabular}{|c|c|c|}
\hline \multicolumn{3}{|l|}{ Dry mass ratio (RMS) } \\
\hline Environment & Benches & \\
\hline Shading & Without reflective material & With reflective material \\
\hline Full sun & $2.63 \mathrm{aA}$ & $2.22 \mathrm{aAB}$ \\
\hline Laying $30 \%$ shading & $2.53 \mathrm{aA}$ & $2.19 \mathrm{aB}$ \\
\hline $35 \%$ Shading Aluminized Screen & $2.74 \mathrm{aA}$ & $2.87 \mathrm{aAB}$ \\
\hline Screen with plastic cover $42 / 50 \%$ shading & $2.34 \mathrm{bA}$ & $2.96 \mathrm{aA}$ \\
\hline $\mathrm{CV}(\%)$ & 17.34 & \\
\hline \multicolumn{3}{|l|}{ Absolute growth rate (TCA) } \\
\hline Full sun & $0.11 \mathrm{aB}$ & $0.08 \mathrm{aB}$ \\
\hline Laying $30 \%$ shading & $0.38 \mathrm{aA}$ & $0.23 \mathrm{bA}$ \\
\hline $35 \%$ Shading Aluminized Screen & $0.41 \mathrm{aA}$ & $0.30 \mathrm{bA}$ \\
\hline Screen with plastic cover $42 / 50 \%$ shading & $0.18 \mathrm{bB}$ & $0.32 \mathrm{aA}$ \\
\hline $\mathrm{CV}(\%)$ & 28.97 & \\
\hline \multicolumn{3}{|l|}{ Dickson quality index (IQD) } \\
\hline Full sun & $0.71 \mathrm{aB}$ & $0.68 \mathrm{aC}$ \\
\hline Laying $30 \%$ shading & $1.92 \mathrm{aA}$ & $1.57 \mathrm{aB}$ \\
\hline $35 \%$ Shading Aluminized Screen & $1.83 \mathrm{aA}$ & $1.61 \mathrm{aAB}$ \\
\hline Screen with plastic cover $42 / 50 \%$ shading & $1.70 \mathrm{bA}$ & $2.13 \mathrm{aA}$ \\
\hline CV $(\%)$ & 19.97 & \\
\hline
\end{tabular}

\section{Conclusions}

The protected environments were favorable to the formation of paricá seedlings.

The environment in full sun formed seedlings more rustic.

The use of reflective material had only effect in the plastic coverage environment with $42 / 50 \%$ shading screen.

\section{References}

Almeida, L. P., alvarenga, A. A., Castro, E. M., Zanela, S. M., \& Vieira, C. V. (2004). Crescimento inicial de plantas de Cryptocaria aschersoniana Mez. submetidas a níveis de radiação solar. Ciência Rural, 34(1), 83-88. https://doi.org/10.1590/S0103-84782004000100013

Almeida, L. S., Maia, N., Ortega, A. R., \& Angelo, A. C. (2005). Crescimento de mudas de Jacaranda puberula Cham. em viveiro submetidas a diferentes níveis de luminosidade. Ciência Florestal, 15(3), 323-329.

Andrade, A. M. D., Moura, M. A. L., Santos, A. B., Carneiro, R. G., \& Silva Junior, R. S. (2014). Radiação fotossinteticamente ativa incidente e refletida acima e abaixo do dossel de floresta de mata atlântica em Coruripe, Alagoas. Revista Brasileira de Meteorologia, 29(1), 68-79. https://doi.org/10.1590/S0102-7786 2014000100007

Azevedo, I. M. G., Alencar, R. M., Barbosa, A. P., \& Almeida, N. O. (2010). Estudo do crescimento e qualidade de mudas de marupá (Simarouba amara Aubl.) em viveiro. Acta Amazonica, 40(1), 157-164. https://doi.org/ 10.1590/S0044-59672010000100020

Banzato, D. A., \& Kronka, S. N. (2006). Experimentação agrícola (p. 237). Jaboticabal: FUNEP.

Barbosa, L. V. A., Benchimol, R. L., Leão, N. V. M., \& Shimizu, E. C. (2013). Influência do sombreamento no desenvolvimento de mudas de paricá (Schizolobium parahyba var. amazonicum (Huber ex Ducke) Barneby) in $17^{\circ}$ Seminário de Iniciação Científica e $1^{\circ}$ Seminário de Pós-graduação da Embrapa Amazônia Oriental. Belém, PA.

Campos, M. A. A., \& Uchida, T. (2002). Influência do sombreamento no crescimento de mudas de três espécies amazônicas. Pesquisa Agropecuária Brasileira, 3, 281-288. https://doi.org/10.1590/S0100-204X2002000 300008 
Caron, B. O., Souza, V. Q., Cantarelli, E. B., Manfron, P. A., Behling, A., \& Eloy, E. (2010). Crescimento em Viveiro de Mudas de Schizolobium parahyba (Vell.) S. F. Blake. Submetidas a Níveis de Sombreamento. Ciência Florestal, 20(4), 683-689. https://doi.org/10.5902/198050982427

Costa, E., Dias, J. G., Binotti, F. F. S., \& Cardoso, E. D. (2015). Telas de Sombreamento e Substratos na Produção de Mudas de Dipteryx alata Vog. Floresta e Ambiente, 22(3), 416-425. https://doi.org/10.1590/ 2179-8087.071714

Costa, E., Ferreira, A. F. A., Silva, P. N. L., \& Nardelli, E. M. V. (2012). Diferentes composições de substratos e ambientes protegidos na formação de mudas de pé-franco de tamarindeiro. Revista Brasileira de Fruticultura, 34(4), 1189-1198. https://doi.org/10.1590/S0100-29452012000400028

Davide, A. C., Faria, J. M. R., \& Botelho, S. A. (1995). Propagação de espécies florestais (p. 40). Belo Horizonte: CEMIG/UFLA/FAEPE.

Gondin, J. C., Silva, J. B., Alves, C. Z., Dutra, A. S., \& Junior, L. E. (2015). Emergência de plântulas de Schizolobium amazonicum Huber ex Ducke (Caesalpinaceae) em diferentes substratos e sombreamento. Revista Ciência Agronômica, 46(2), 329-338. https://doi.org/10.5935/1806-6690.20150012

IBGE (Instituto Brasileiro de Geografia e Estatística). (2012). Indicadores de desenvolvimento sustentável (9th ed., p. 350). Rio de Janeiro: IBGE.

Koppen, W., \& Geiger, R. (1961). Handbuck der Klimatologie. Berlin, Germany.

Lima, J. D., Silva, B. M. S., Moraes, W. S., Dantas, V. A. V., \& Almeida, C. C. (2008). Efeitos da luminosidade no crescimento de mudas de Caesalpinia ferrea Mart. Ex Tul. (Leguminosae, Caesalpinoideae). Acta Amazonica, 38(1), 5-10. https://doi.org/10.1590/S0044-59672008000100002

Matos, G. D., Frigotto, T., Martins, A. P. M., \& Brun, E. J. (2009). Desenvolvimento de mudas de paricá (Schizolobium amazonicum Huber ex Ducke) em substrato orgânico-Estudo de Caso. Synergismus Scyentifica, 4(1).

Melo, R. R., \& Cunha, M. C. L. (2008). Crescimento inicial de mudas de mulungu (Erythrina velutina Wild.) sob diferentes níveis de luminosidade. Ambiência-Revista do Setor de Ciências Agrárias e Ambientais, 4(1).

Rosa, L. S. (2006). Ecologia e silvicultura do paricá (Schizolobium amazonicum Huber ex. Ducke) na Amazônia brasileira. Revista de Ciências Agrarias, 45, 107-146.

Rosa, L. S., Vieira, T. A., Santos, D. S., \& Silva, L. C. B. (2009). Emergência, crescimento e padrão de qualidade de mudas de Schizolobium amazonicum Huber ex Ducke sob diferentes níveis de sombreamento e profundidades de semeadura. Revista de Ciências Agrárias, 52, 87-98.

Santos, T. V., Lopes, T. C., Silva, A. G., Paula, R. C. M., Costa, E., \& Binotti, F. F. S. (2017). Produção de mudas de maracujá amarelo com diferentes materiais refletores sobre bancada. Revista de Agricultura Neotropical, 4(4), 26-32. https://doi.org/10.32404/rean.v4i4.1781

Scalon, S. P. Q., Mussury, R. M., Rigoni, M. R., \& Scalon Filho, H. (2003). Crescimento inicial de mudas de Bombacopsis glabra (Pasq.) A. Robyns sob condição de sombreamento. Revista Árvore, 27(6), 753-758.

Taiz, L., \& Zeiger, E. (2004). Fisiologia Vegetal (p. 719). Porto Alegre: Artmed.

\section{Copyrights}

Copyright for this article is retained by the author(s), with first publication rights granted to the journal.

This is an open-access article distributed under the terms and conditions of the Creative Commons Attribution license (http://creativecommons.org/licenses/by/4.0/). 